Syntax Literate: Jurnal Ilmiah Indonesia p-ISSN: 2541-0849 e-ISSN: 2548-1398

Vol. 7, No. 1, Januari 2022

\title{
ANALISIS KEBIJAKAN PERIZINAN TENAGA BIDAN PRAKTIK MANDIRI DI PROVINSI DKI JAKARTA: SEBUAH TINJAUAN NARATIF
}

\section{Edward Lumban Raja, Puput Oktamianti}

Fakultas Kesehatan Masyarakat, Universitas Indonesia (UI) Depok Jawa Barat, Indonesia

Email: edwraja2@gmail.com, oktamianti@gmail.com

\begin{abstract}
Abstrak
Mengacu pada Undang-Undang Nomor 36 Tahun 2009 tentang kesehatan dan Undang-Undang Nomor 36 Tahun 2014 tentang tenaga kesehatan yang menjelaskan bahwa setiap tenaga kesehatan yang menjalankan praktik wajib memiliki izin dari otoritas pemerintah setempat yang dibuktikan dengan Surat Izin Praktik (SIPB). Peraturan Menteri Kesehatan Nomor 28 tahum 2017 tentang Izin dan Penyelenggaraan Praktik Bidan Menjelaskan seorang Bidan harus meiliki SIPB. Fenomena yang terjadi di Provinsi DKI Jakarta masih ditemukan Praktik Bidan Mandiri yang tidak memiliki Izin. Tercatat sebanyak 145 tenaga Bidan praktik Mandiri Berpraktik tanpa memiliki Izin dari total 505 bidan praktik Mandiri. Tujuan dari penelitian ini adalah untuk menganalisis proses Permohonan Surat Izin Praktik Bidan dan untuk menganalisa kendala-kendala yang menghambat permohonan. Metode yang digunakan adalah Narrative Review yaitu menganalisis dan mengevaluasi beberapa hasil penelitian sebelumnya dengan mengikuti kaidah dan alur penelitian yang dimulai dari penentuan topik terkait perizinan praktik bidan mandiri, praktik tenaga kesehatan, seleksi literatur sesuai kriteria yang telah ditentukan yakni jurnal yang terbaru dan relevan dengan topik penelitian. Hasil menunjukkan bahwa permohonan SIPB di Provinsi DKI Jakarta belum sepenuhnya sesuai dengan Peraturan Menteri Kesehatan Nomor 28 tahum 2017 tentang Izin dan Penyelenggaraan Praktik Bidan. Ditemukan bebrapa Kendala dalam penerapan Peraturan terkait perizinan dan permasalahan Internal Bidan Sendiri serta Peraturan yang ada di Organisasi.
\end{abstract}

Kata Kunci: perizinan bidan; bidan; kesehatan

\section{Abstract}

According to Law Number 36 of 2009 concerning health and Law Number 36 of 2014 concerning health workers which explains that every health worker who practices practice is required to have a permit from the local government authority as evidenced by a Practice Permit (SIPB). Regulation of the Minister of Health Number 28 of 2017 concerning Permits and Implementation of Midwifery Practices Explains that a Midwife must have a SIPB. The phenomenon that occurs in DKI Jakarta Province is still found in the practice of independent midwives who do not have a permit. There were 145 practicing independent midwives practicing without a permit from a total of 505 midwives independent practice. The purpose of this

$\begin{array}{ll}\text { How to cite: } & \text { Raja. E.L \& Puput Oktamianti (2022) Analisis Kebijakan Perizinan Tenaga Bidan Praktik Mandiri di } \\ & \text { Provinsi DKI Jakarta: Sebuah Tinjauan Naratif. Syntax Literate: Jurnal Ilmiah Indonesia, 7(1). } \\ & \text { http://dx.doi.org/10.36418/ Syntax-Literate.v7i1.6042 } \\ \text { E-ISSN: } & 2548-1398 \\ \text { Published by: } & \text { Ridwan Institute }\end{array}$


study is to analyze the process of applying for a Midwife's Practice License and to analyze the obstacles that hinder the application. The method used is Narrative Review, which analyzes and evaluates several previous research results by following the rules and research flow starting from determining topics related to licensing the practice of independent midwives, practicing health workers, selecting literature according to predetermined criteria, namely the latest journals and relevant to the topic. study. The results show that the SIPB application in DKI Jakarta Province is not fully in accordance with the Regulation of the Minister of Health Number 28 of 2017 concerning Permits and Implementation of Midwife Practices. Found several obstacles in the application of regulations related to licensing and internal problems of Midwives themselves as well as existing regulations in the organization.

Keywords: licensing; midwife; health

Received: 2021-12-20; Accepted: 2022-01-05; Published: 2022-01-15

\section{Pendahuluan}

Sumber daya manusia Kesehatan (SDMK) sangat diperlukan dalam meningkatkan derajat kesehatan masyarakat di suatu Negara (Lette, 2020). Sumber daya manusia kesehatan adalah tenaga kesehatan (termasuk tenaga kesehatan strategis) dan tenaga pendukung atau penunjang kesehatan yang terlibat dan bekerja serta mengabdikan dirinya dalam upaya dan manajemen kesehatan (Hajriati, Arman, \& Muchlis, 2021). Survei pendahuluan yang dilakukan di salah satu Bidan Praktik Mandiri didapatkan data bahwa ada bidan praktik yang diduga melakukan praktik kebidanan tidak sesuai dengan kewenangan sehingga menyebabkan terjadinya kematian pada ibu hamil. Pertolongan persalinan dilakukan oleh bidan yang masih magang, sehingga bidan tersebut menyalahi aturan karena melimpahkan kewenangan pada calon bidan yang belum memiliki sertifikasi kompetensi dan Perizinan (Lutfiana \& Wulandari, 2020). Bidan dalam menjalankan tugasnya harus memiliki pendidikan yang formal, mempunyai sistem pelayanan, kode etik dan etika kebidanan dalam melaksanakan tugas dan tanggung jawabnya secara professional, dalam hal ini tercantum pada Peraturan Menteri Kesehatan No 28 Tahun 2017 Tentang Izin Dan Penyelenggaraan Praktik Bidan. Menurut Pasal 23 Undang-Undang Nomor 36 Tahun 2009 disebutkan bahwa tenaga kesehatan berwenang untuk menyelenggarakan pelayanan kesehatan (Nomor, 28AD). Namun dalam ayat ini dijelaskan bahwa kewenangan yang dimaksud dalam ayat ini adalah kewenangan yang diberikan berdasarkan pendidikannya setelah melalui proses registrasi dan pemberian izin dari pemerintah sesuai dengan peraturan perundangundangan (Nuryuniarti \& Nurmahmudah, 2019).

Saat ini pelayanan kebidan di Indonesia diatur berdasarkan Undang-Undang Republik Indonesia Nomor 4 Tahun 2019 Tentang Kebidanan yang disahkan pada tanggal 13 Maret 2019 (Telaumbanua, 2019). Dalam undang-undang ini dinyatakan bahwa segala sesuatu yang berhubungan dengan bidan dalam memberikan pelayanan kebidanan kepada perempuan selama masa sebelum hamil, masa kehamilan, persalinan, 
pasca persalinan, masa nifas, bayi baru lahir, bayi, balita, dan anak prasekolah, termasuk kesehatan reproduksi perempuan dan keluarga berencana sesuai dengan tugas dan wewenangnya.

Provinsi DKI Jakarta dengan segala infrastruktur dan APBD Provinsi terbesar seIndonesia termasuk dalam lima besar provinsi dengan rasio tenaga bidan yang baik. Tercatat menurut PPSDMK Kementerian Kesehatan, Rasio tenaga bidang di DKI Jakarta sudah berada pada angka 1:66 per 100.000 penduduk. Ini artinya jumlah bidan di DKI Jakarta sudah terbilang mencukupi dalam kebutuhan. Data PPSDM Kemenkes juga mencatat pada tahun 2020 terdapat 6.284 orang bidan yang terdaftar di DKI Jakarta dengan 573 orang bidan melakukan praktik mandiri, sedangkan sisanya berpraktik di instansi rumah sakit ataupun puskesmas. Jakarta Pusat sebagai epicentrum Ibu Kota terdapat 42 orang bidan berpraktik secara mandiri namun tidak semuanya memiliki izin, $40 \%$ diantaranya masih belum memiliki izin praktik mandiri.

Pada praktiknya jelas proses pelayanannya diharuskan adanya perizinan yang terdaftar. Pada Bagian Kedua UU No 4 tahun 2019 pasal 25 ayat (1) menjelaskan bahwa bidan yang akan menjalankan praktik kebidanan wajib memiliki izin praktik. Selanjutnya pada ayat (2) bahwa izin praktik sebagaimana dimaksud pada ayat (1) diberikan dalam bentuk SIPB (surat izin praktik bidan) (Firmanto, 2019).

\section{Metode Penelitian}

Penelitian ini menggunakan pendekatan studi Narrative Review yang berfokus pada evaluasi beberapa hasil penelitian sebelumnya dengan mengikuti kaidah dan alur penelitian yang dimulai dari penentuan topik terkait perizinan praktik bidan mandiri, penelusuran literatur berdasarkan database artikel terkait perizinan praktik tenaga kesehatan, seleksi literatur sesuai kriteria yang telah ditentukan yakni jurnal yang terbaru dan relevan dengan topik penelitian (Jayanti, Keb, Anis, \& Keb, 2021). Penggolahan data dalam penelitian ini dilakukan dengan melakukan review jurnal terbaru, dan mengkaitkan fenomena perizinan praktik bidan mandiri serta melakukan review regulasi yang ada terkait perizinan praktik bidan mandiri. Hasil sintesa pengambilan kesimpulan dalam penelitian ini diambil secara objektif dengan menggunakan analisa dan kompetensi yang dimiliki oleh peneliti.

\section{Hasil dan Pembahasan}

\section{A. Hasil Penelitian}

\section{Perizinan}

Perizinan adalah pemberian legalitas kepada seseorang atau pelaku usaha/kegiatan tertentu, baik dalam bentuk izin maupun tanda daftar usaha (Dewi, 2021). Izin adalah suatu instrumen yang paling banyak digunakan dalam hukum administrasi. Guna melindungi masyarakat penerima pelayanan kesehatan, setiap tenaga kesehatan yang hendak menjalankan praktik keprofesiannya wajib memiliki izin sesuai dengan ketentuan peraturan perundang-undangan. Mengacu pada Undang-Undang Nomor 36 Tahun 2009 
tentang kesehatan dan Undang-Undang Nomor 36 Tahun 2014 tentang tenaga kesehatan yang menjelaskan bahwa setiap tenaga kesehatan yang menjalankan praktik wajib memiliki izin dari otoritas pemerintah setempat yang dibuktikan dengan Surat Izin Praktik (SIP). Pada tahun 2020 tercatat Jumlah Bidan Praktik Mandiri di Provinsi DKI Jakarta Sebanyak 573 orang, 393 orang (69\%) memiliki SIPB dan yang tidak memiliki SIPB sebanyak 180 orang (31\%). Rekomendasi dari Organisai Profesi yang dalam hal ini Ikatan Bidan Indonesia (IBI) mutlak diperlukan sebagai syarat permohonan SIPB. Untuk memperoleh rekomendasi dari IBI anggota wajib mengikuti Midwifery Update (MU). Hal ini tidak selaras jika dikaitkan dengan persyaratan untuk memperoleh rekomendasi dari organisasi profesi, karena tidak sem

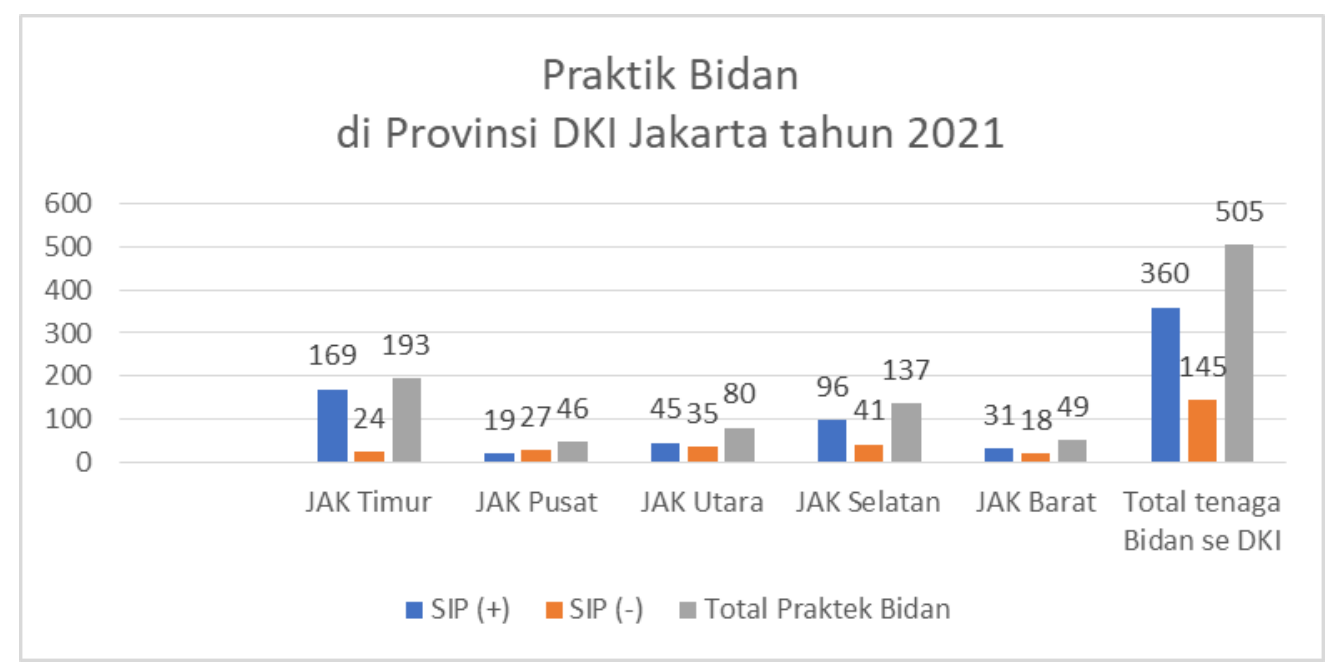

Gambar 1

Grafik Praktik Mandiri Bidan di Provinsi DKI Jakarta 2021

Data diatas menjelaskan bahwa terdapat total dari 505 orang bidan yang melakukan praktik mandiri, Jakarta Timur menjadi kota yang dengan praktik bidan mandiri terbanyak, sedangkan Jakarta Pusat menjadi kota dengan praktik bidan mandiri paling sedikit. Dari total 505 orang bidan praktik mandiri yang ada di Provinsi DKI, masih ditemukan sebanyak 145 orang diantaranya masih belum memilki izin praktik yang terdaftar, hal ini menjadi pertanyaan bahwa dengan Provinsi DKI Jakarta sebagai Pusat ibukota dan rolemodel bagi Provinsi Lain ternyata kondisi ini masih terjadi.

\section{Persyaratan dalam penyelenggaraan praktik mandiri bidan}

Pada Permenkes No. 28 Tahun 2017 tentang izin dan penyelengaraan praktik mandiri bidan pasal 1 ayat (5) menjelaskan bahwa Praktik Mandiri Bidan adalah tempat pelaksanaan rangkaian kegiatan pelayanan kebidanan yang dilakukan oleh bidan secara perorangan. Bidan yang menyelenggarakan Praktik Mandiri harus memenuhi persyaratan yang telah ditentukan untuk dikeluarkannya Surat Izin Praktik Bidan (SIPB). Kewenangan bidan terdiri dari 
pelayanan kesehatan ibu, pelayanan kesehatan anak, pelayanan kesehatan reproduksi dan keluarga berencana.

Jika mengacu pada Kepmenkes Nomor 900/Menkes/SK/VII/II/2002 tentang Registrasi dan Praktik Bidan. Bidan adalah seorang wanita yang telah mengikuti program pendidikan bidan dan lulus ujian sesuai dengan persyaratan yang berlaku. Sedangkan registrasi adalah proses pendaftaran, pendokumentasian dan pengakuan terhadap bidan, setelah dinyatakan memenuhi minimal kompetensi inti atau standar penampilan minimal yang ditetapkan, sehingga secara fisik dan mental mampu melaksanakan praktik profesinya. Surat Izin Bidan selanjutnya disebut SIB adalah bukti tertulis pemberian kewenangan untuk menjalankan pelayanan asuhan kebidanan di seluruh wilayah Republik Indonesia. Kemudian penjelasan terkait definisi praktik bidan adalah serangkaian kegiatan pelayanan kesehatan yang diberikan oleh bidan kepada pasien baik individu, keluarga, atau masyarakat sesuai dengan kewenangan dan kemampuannya. Karenanya Surat Izin Praktik Bidan selanjutnya disebut SIPB adalah bukti tertulis yang diberikan kepada bidan untuk dapat menjalankan praktik bidan. Sesuai standar profesi. Sedangkan standar profesi adalah pedoman yang harus dipergunakan sebagai petunjuk dalam melaksanakan profesi secara baik.

Persyaratan yang ditentukan dalam proses perizinan praktik mandiri bidan meliputi persyaratan lokasi, bangunan, prasarana, peralatan, serta obat dan bahan habis pakai, tercantum dalam Permenkes No.28 Tahun 2017 tentang izin dan penyelenggaraan praktik bidan dalam pasal (30) sampai pasal (36) yakni;

a. Persyaratan lokasi berupa Praktik Mandiri Bidan harus berada pada lokasi yang mudah untuk akses rujukan dan memperhatikan aspek kesehatan lingkungan. Persyaratan bangunan meliputi ruang dalam bangunan Praktik Mandiri Bidan yang terdiri dari Ruang tunggu, ruang periksa, ruang bersalin, ruang nifas, WC/kamar mandi

b. Bangunan praktik Mandiri bidan harus bersifat permanen dan tidak bergabung fisik bangunan lainnya. Sebagaimana tidak bergabung fisik bangunan lainnya, yakni tidak termasuk rumah tinggal perorangan, apartemen, rumah toko, rumah kantor, rumah susun, dan bangunan yang sejenis. Dalam hal praktik mandiri berada di rumah tinggal perorangan, akses pintu keluar masuk tempat praktik harus terpisah dari tempat tinggal perorangan. Bangunan praktik mandiri Bidan harus memperhatikan fungsi, keamanan, kenyamanan dan kemudahan dalam pemberian pelayanan serta perlindungan keselamatan dan

c. Persyaratan prasarana Praktik Mandiri Bidan paling sedikit memiliki; Sistem air bersih, Sistem kelistrikan atau pencahayaan yang cukup, Ventilasi/sirkulasi udara yang baik, Prasarana lain sesuai kebutuhan.

d. Bidan yang akan menjalankan praktik dan/atau pekerjaan keprofesiannya harus kompeten yang di buktikan dengan Sertifikat Kompetensi atau 
Sertifikat Profesi. Sesuai Undang-undang No. 36 tahun 2014, pasal 46 bahwa setiap tenaga kesehatan yang praktik harus memiliki izin demikian juga dengan seorang bidan yang akan menjalankan profesinya. Surat Izin Praktik Bidan (SIPB) ditetapkan sebagai bukti tertulis yang diberikan oleh pemerintah kepada bidan yang akan menjalankan praktik kebidanan setelah memenuhi persyaratan. Untuk mendapatkan SIPB, syaratnya adalah adanya Surat Tanda registrasi (STR) yang masih berlaku. Surat Tanda Registrasi berlaku selama 5 tahun dengan syarat mendapatkan STR yakni harus memiliki Sertifikat Kompetensi atau Sertifikat Profesi. Kebijakan Pengrus Pusat Ikatan Bidan Indonesia (IBI) utk Resertifikasi dilakukan melalui penilaian portofolio, yaitu selama 5 (lima) tahun harus menadapatkan sejumlah 25 (dua puluh lima) kredit profesi, 2 (dua) kredit profesi diantaranya diperoleh melalui Midwifery Update yang diselenggarakan oleh organisasi profesi.

Midwifery Update merupakan salah satu pelatihan klinis wajib yang harus dipenuhi oleh setiap bidan dalam pengurusan re-sertifikasi STR. Pada pelatihan Midwifery Upadate, seluruh peserta akan dibekali dengan beberapa materi kebidanan sebagai upaya menjaga mutu serta meningkatkan keterampilan dan kompetensi para bidan, sehingga kemdian diharapkan dapat memberikan pelayanan berkualitas terhadap kesehatan ibu dan bayi, balita, kesehatan reproduksi serta pelayanan keluarga berencana. Kemudian akan dijelaskan secara mendetail alur tata cara pengurusan STR selanjutnya.

\section{Prosedur Alur Perizinan Praktik Bidan}

Proses alur kepengurusan perizinan praktik bidan mandiri dimulai dari melengkapi persyaratan surat keterangan dari pimpinan fasilitas Pelayanan. Rekomendasi dikeluarkan oleh Dinas Kesehatan Kabupaten Kota (Suku Dinas Kesehatan Kota Administrasi). Suku Dinas Kesehatan Kota Administrasi melakukan kunjungan atau visitasi bersama dengan PTSP (Pelayanan Terpadu Satu Pintu) untuk kemudian dilakukan wawancarara terkait kelengkapan fasilitas pelayanan, administrasi dan setelah itu kemudian dipaparkan temuan yang harus ditindak lanjuti. Suku Dinas Kesehatan akan memberikan waktu 14 hari agar Pemohon memperbaiki semua temuan yang didapatkan saat kunjungan, setelah itu akan membuat rekomendasi penerbitan izin praktik ke Pelayanan terpadu Satu Pintu.

\section{Pergub DKI Jakarta No 159 Tahun 2019}

Sejalan dengan Peraturan Menteri Kesehatan No. 28 Tahun 2017 tentang Praktik Bidan Mandiri wajib memiliki SIPB dalam menjalankan praktiknya, Peraturan Gubernur DKI Jakarta No 159 tahun 2019 tentang Organisasi dan tata kerja Dinas Kesehatan Pasal 33 menyebutkan Pemantauan dan evaluasi di bidang sumber daya manusia kesehatan termasuk pengoordinasian penilaian teknis bersama dan pemberian bahan rekomendasi kepada Dinas Penanaman Modal dan Pelayanan Terpadu Satu Pintu dalam rangka penerbitan perizinan dan 
non perizinan di bidang sumber daya manusia kesehatan. Pengawasan dan pengendalian perizinan dan non perizinan di Bidang kesehatan sesuai lingkup tugas dan fungsinya, melaksanakan pembinaan tenaga kesehatan, memberikan bimbingan teknis dan supervisi di bidang sumber daya manusia kesehatan sumber daya manusia kesehatan. Upaya yang telah dilakukan oleh Dinas Kesehatan Provinsi DKI Jakarta untuk sosialisasi perizinan tenaga kesehatan baik melalui forum komunikasi tenaga praktik mandiri bidan maupun melaksanakan koordinasi dengan organisasi profesi kebidanan dalam hal ini Ikatan Bidan Indonesia (IBI) dengan tujuan untuk menurunkan jumlah praktik mandiri bidan yang tidak memiliki izin Praktik mengingat banyaknya bidan di Provinsi DKI Jakarta yang tidak patuh dalam memiliki izin praktik.

5. Peraturan Gubernur Provinsi DKI Jakarta No 47 tahun 2017 tentang Petunjuk Pelaksanaan Pelayanan Terpadu 1 pintu

Pemberian izin kepada tenaga kesehatan merupakan kewenangan dari Dinas Penanaman Modal dan Pelayanan Terpadu Satu Pintu (DPMPTSP) sesuai dengan Peraturan Gubernur Provinsi DKI Jakarta No 47 tahun 2017 tentang Petunjuk Pelaksanaan Pelayanan Terpadu 1 pintu Bab III Pasal 3 yang berisi Kewenangan DPMPTSP meliputi perizinan di bidang Kesehatan. Hal ini dilakukan guna menciptakan keharmonisan perizinan dan demi mempermudah adanya pendataan dan juga monitoring terkait perizinan yang sudah dan belum dilakukan serta sesuai tujuan utama yakni meningkatkan kualitas pelayanan dan menjamin aspek legalitas praktik bidan mandiri di Porvinsi DKI Jakarta.

\section{B. Pembahasan}

1. Permohonan Surat Izin Praktik Bidan (SIPB) Berdasarkan Peraturan Menteri Kesehatan Nomor 28 TAHUN 2017 Tentang Izin Dan Penyelenggaraan Praktik Bidan di Provinsi DKI Jakarta.

Penyediaan Pelayanan kesehatan untuk ibu dan bayi baru lahir yang berkualitas bergantung pada tenaga kebidanan yang profesional kompeten dan efektif. untuk itu perlu didukung dengan kompetensi dan pelayanan yang profesional seorang bidan (Annabel et.all, 2018). Sesuai dengan amanah Undang-Undang yang menyatakan bahwa Pemerintah bertanggung jawab atas ketersediaan sumber daya kesehatan dan penyelenggaraan pelayanan kesehatan. Untuk itu sudah seharusnya kebijakan Pemerintah juga sejalan dengan mandat rakyat untuk mendapatkan pelayanan kesehatan yang dilakukan oleh tenaga kesehatan yang kompeten dan memiliki legalitas dalam hal perizinan tenaga kesehatan (Nursalam, 2013).

Implementasi kebijakan terkait praktik perizinan tenaga kesehatan masih mengacu pada Undang-Undang Tenaga Kesehatan No 5 dan Permenkes No 28 tahun 2017, yang mengamanatkan semua tenaga kesehatan harus memiliki STR. STR adalah bukti legalitas tenaga kesehatan dalam melaksanakan praktik. Proses registrasi diperoleh dari sejumlah kegiatan yang dibuktikan dengan portofolio. Seorang bidan diharuskan melengkapi portofolio yaitu bukti untuk menunjukkan 
bagaimana mereka telah memenuhi persayaratan dengan dengan menguraikan pengalaman praktik kebidanan untuk mendapatkan registrasi kebidanan. Portofolio juga dapat digunakan untuk mendokumentasiakn jam praktik klinis pengalaman dan program studi, meskipun tidak ada jam wajib khusu praktik klinis dan standard (Et.all, 2020).

Kebijakan tersebut dikaitkan dalam Pedoman Pelaksanaan Pembinaan dan Pengawasan di Dinas Kesehatan Provinsi dan 5 Suku Dinas Kesehatan Kota Administrasi. Kebijakan ini juga yang mendasari PTSP sebagai lembaga yang menerbitkan Perijianan semua tenaga kesehatan Mewajibakan STR dalam penerbitan SIP. Pemberian izin kepada tenaga kesehatan merupakan kewenangan dari Dinas Penanaman Modal dan Pelayanan Terpadu Satu pintu (DPMPTSP). sesuai dengan Peraturan Gubernur Provinsi DKI Jakarta No 47 tahun 2017 tentang Petunjuk Pelaksanaan Pelayanan Terpadu 1 pintu Bab III Pasal 3 yang berisi Kewenangan DPMPTSP meliputi perizinan di bidang Kesehatan. DPMPTSP belum memberlakukan hal yang sama pada bidan Pendamping karena SIP perizinan tenaga bidan hanya diterbitkan untuk 1 orang tenaga bidan dalam 1 lokasi praktik. berbeda dengan wilayah lain seperti di Jakarta Utara dan Jakarta Timur. Perbedaan kebijakan ini tentunya menimbulkan kegamangan di Praktik bidan mandiri yang akan mengurus izin praktik mandiri.

Menurut data SISDMK Dinas Kesehatan di Provinsi DKI Jakarta pada tahun 2020 terdapat 505 Bidan Praktik Mandiri yang berpraktik di Provinsi DKI Jakarta. yang tersebar di 5 Kota Administrasi yaitu Jakarta Pusat, Jakarta Timur, Jakarta Barat, Jakarta selatan dan Jakarta Utara. Sayangnya dari 505 BPM masih banyak ditemukan BPM yang berpraktik tanpa izin. Merujuk dari data SISDMK Dinas Kesehatan Provinsi DKI Jakarta dapat dijabarkan sebaran Bidan praktik Mandiri yang tidak memili izin di antaranya: Dari 46 orang BPM di Jakarta Pusat terdapat 19 orang $(41 \%)$ yang memiliki izin sedangkan yang tidak memiliki izin sebanyak 27 orang (59\%). Di wilayah kota Administrasi Jakarta Timur dari 193 orang BPM terdapat 169 orang (88\%) yang memiliki izin sedangkan yang tidak memiliki izin sebanyak 24 orang (12\%). Di wilayah kota Administrasi Jakarta Utara dari 80 orang BPM terdapat 45 orang $(56 \%)$ yang memiliki izin praktik sedangkan yang tidak memiliki izin sebanyak 35 orang (44\%). Di wilayah kota Administrasi Jakarta Selatan dari 137 orang BPM terdapat 96 orang $(70 \%)$ yang memiliki izin sedangkan yang tidak memiliki izin sebanyak 41 orang (30\%). Di wilayah kota Administrasi Jakarta Barat dari 49 orang BPM terdapat 31 orang $(71 \%)$ yang memiliki izin sedangkan yang tidak memiliki izin sebanyak 18 orang (37\%). Dari total 505 Praktik Mandiri terdapat 145 (29\%) Praktik mandiri yang tidak memiliki izin dan masih aktif berpraktik. tentu angka yang cukup tinggi untuk Provinsi DKI Jakarta Yang merupakan Barometer terhadap Provinsi lain. Penelitian tentang banyaknya tenaga bidan yang tidak memiliki izin praktik sangat penting bagi pembuat kebijakan dan pendidik (Gibis et al., 2012). Penelitian terhadap bidan menunjukkan 
menurunnnya minat tenaga kesehatan Bidan untuk melaksanakan praktik mandiri dan cenderung mengabaikan aspek legal dalam hal ini izin praktik sehingga banyak ditemukan Bidan praktik mandiri (BPM tidak memiliki izin praktik). Fenomena ini bertoal belakang dengan amanat Undang-Undang yang mewajibakan tenaga kesehatan yang mengharuskan semua tenaga kesehatan yang berpraktik agar memilik izin praktik.

Salah satu faktor banyaknya tenaga Bidan tanpa izin adalah kurangnya pengawasan dari Dinas Kesehatan terhadap bidan praktik mandiri. Pelaksanaan pengawasan ini didasarkan pada UU no 4 tahun 2019 pada BAB X tentang Pembinaan Dan Pengawasan Pasal 16 (1) Bidan yang berpraktik di Fasilitas Pelayanan Kesehatan berupa puskesmas sebagaimana dimaksud dalam Pasal 15 ayat (3) huruf b meliputi a. Bidan yang melakukan praktik kebidanannya di puskesmas; dan b. Bidan desa. -10- (2) Bidan desa sebagaimana dimaksud pada ayat (1) huruf b merupakan Bidan yang memiliki SIPB di puskesmas, dan bertempat tinggal serta mendapatkan penugasan untuk melaksanakan Praktik Kebidanan dari Pemerintah Daerah pada satu desa/kelurahan dalam wilayah kerja puskesmas yang bersangkutan. (3) Praktik Bidan desa sebagaimana dimaksud pada ayat (2) merupakan tempat praktik bidan desa sebagai jaringan Puskesmas. (4) Dalam rangka penjaminan mutu pelayanan kesehatan praktik Bidan desa sebagai jaringan Puskesmas sebagaimana dimaksud pada ayat (3), dinas kesehatan kabupaten/kota setempat harus melakukan penilaian pemenuhan persyaratan tempat yang akan dipergunakan untuk penyelenggaraan praktik Bidan desa dengan menggunakan Formulir 1 yang merupakan bagian tidak terpisahkan dari Peraturan Menteri ini. (5) Hasil penilaian sebagaimana dimaksud pada ayat (4) menjadi dasar rekomendasi sebagaimana dimaksud dalam Pasal 8 ayat (1) huruf f, sebelum SIPB untuk Bidan desa diterbitkan. Pasal 69 (1) Pemerintah Pusat dan Pemerintah Daerah melakukan pembinaan dan pengawasan Bidan dengan melibatkan Konsil dan Organisasi Profesi Bidan sesuai dengan kewenangan.

Kemudian diturunkan dalam Permenkes No. 28 Tahun 2017 BAB VI Pembinaan Dan Pengawasan Pasal 46 (1) Menteri, Kepala Dinas Kesehatan Provinsi, dan/atau Kepala Dinas Kesehatan Kabupaten/Kota melakukan pembinaan dan pengawasan terhadap pelaksanaan praktik bidan sesuai dengan kewenangan masingmasing. (2) Dalam melakukan pembinaan sebagaimana dimaksud pada ayat (1), Menteri, Dinas Kesehatan Provinsi, Dinas Kesehatan Kabupaten/Kota dapat mengikutsertakan organisasi profesi. (3) Pembinaan dan pengawasan sebagaimana dimaksud pada ayat (1) diarahkan untuk meningkatkan mutu pelayanan, keselamatan pasien, dan melindungi masyarakat terhadap segala kemungkinan yang dapat menimbulkan bahaya bagi kesehatan.

(4) Dalam rangka pelaksanaan pengawasan sebagaimana dimaksud pada ayat (1), Menteri, Dinas Kesehatan Provinsi, Dinas Kesehatan Kabupaten/Kota dapat memberikan tindakan administratif kepada bidan yang melakukan pelanggaran 
terhadap ketentuan penyelenggaraan praktik. (5) Tindakan administratif sebagaimana dimaksud pada ayat (1) dilakukan melalui: a. teguran lisan; b. teguran tertulis; c. pencabutan SIP untuk sementara paling lama 1 (satu) tahun; atau d. pencabutan SIPB selamanya.

Selanjutnya dalam Pergub 159 tahun 2019 Tentang Organisasi dan Tata Kerja Dinas Kesehatan Pasal 44 ayat (3) Seksi Sumber daya Kesehatan memiliki tugas Pembinaan dan pengawasan di bidang di bidang sumberdaya kesehatan di wilayah Kota Administrasi, meliputi kefarmasian, alat kesehatan dan perbekalan kesehatan rumah tangga serta sumber daya manusia kesehatan;

Dengan dilakukan pengawasan diharapkan jumlah praktik mandiri yang berprakik tanpa izin dapat diminimalir dengan melakukan penguatan pentingnya perizinan dan mengarahkan para BPM untuk mengurus perizinan.

\section{Rekomendasi Dari Organisasi Profesi (IBI)}

Rekomendasi IBI mutlak diperlukan dalam pengajuan permohonan SIPB baru atau pembaruan SIPB. Di Provinsi DKI Jakarta untuk mendapatakan rekomendasi IBI wajib memiliki sertifikat MU (Midwifery Update).

\section{Kendala Yang Ditemukan Dalam Proses Perizinan}

Kendala-Kendala Yang Menghambat Permohonan Surat Izin Praktik Bidan (SIPB) Berdasarkan Dalam Peraturan Menteri Kesehatan Nomor 28 tahum 2017Tentang Izin Dan Penyelenggaraan Praktik Bidan di Provini DKI Jakarta. Robert B. Seidman menyatakan bahwa tindakan apapun yang akan diambil baik oleh pemegang peran, lembaga-lembaga pelaksana maupun pembuat Undangundang selalu berada dalam lingkup kompleksitas kekuatan sosial, budaya, ekonomi dan politik, dan lain sebagainya. Seluruh kekuatan-kekuatan sosial itu selalu ikut bekerja dalam setiap upaya untuk memfungsikan peraturan-peraturan yang berlaku, menerapkan sanksi- sanksinya, dan dalam seluruh aktivitas lembaga-lembaga pelaksanaannya.

a) Hambatan dalam permohonan SIPB kaitannya dengan lembaga pembuat peraturan adalah Peraturan Menteri Kesehatan Dalam Peraturan Menteri Kesehatan Nomor 28 tahum 2017. Berdasarkan Pasal 23 UU No. 36 Tahun 2009 Tentang Kesehatan bahwa tenaga kesehatan dalam menyelenggarakan pelayanan kesehatan, wajib memiliki izin dari pemerintah. Pasal 46 (1) UU Nomor 36 Tahun 2014 tentang Tenaga Kesehatan bahwa setiap tenaga kesehatan yang menjalankan praktik di bidang kesehatan wajib memilik izin. Permohonan izin harus menempuh prosedur tertentu yang ditentukan oleh pemerintah, selaku pemberi izin. Syarat-syarat dalam izin itu bersifat konstitusif dan kondisional.

b) Hambatan dalam permohonan SIPB kaitannya dengan penerapan peraturan adalah Dinas Kesehatan Provinsi DKI Jakarta dalam memberikan kebijakan memebrikan rekomendasi tidak memiliki daasar yang kuat terhadap prosedur pemberian ijin dlaam dua tempat yang sama. 
c) Hambatan yang berkaitan dengan pemangku peran adalah pengajuan permohonan dan pembaruan SIPB dilakukan secara kolektif per ranting tiap kecamatan, dimana tidak semua BPM masa berlaku SIPB berbeda. Kepatuhan setiap anggota untuk mengumpulkan persyaratan SIPB juga berbeda ada yang segera mengumpulkan dan ada juga yang lambat, hal ini yang menyebabkan proses pengajuan SIPB berlangsung lama.

\section{Kesimpulan}

Berdasarkan hasil penelitian ini, maka dapat disimpulkan: Penerapan UndangUndang Nomor 36 Tahun 2014 dan Peraturan Menteri Kesehatan Nomor 28 tahum 2017 tentang Izin dan Penyelenggaraan Praktik Bidan, tingkat efektivitasnya masih rendah. Berdasarkan Analisa yang dilakukan terdapat beberapa kendala yang dihadapi terkait masih adanya Bidan Praktik mandiri yang tidak memiliki SIPB antara lain:

a. Faktor Hukumnya

Dalam Peraturan Menteri Kesehatan Nomor 28 tahum 2017 tentang Izin dan Penyelenggaraan Praktik Bidan, Bab IV Pasal 30 ayat (1) yang menatakan bahwa Bidan yang menyelenggarakan Praktik Mandiri Bidan harus memenuhi persyaratan, selain ketentuan persyaratan memperoleh SIPB sebagaimana dimaksud dalam pasal 8 ayat (1). Pada pelaksanaannya SIPB didapatkan Setelah Praktik Mandiri memiliki STR. Untuk mendapatkan STR seorang bidan praktik mandiri hars memiliki Sertifikat Midwifery Update (MU). Hal in dirasa cukup memberatkan bagi bidan praktik mandiri karena merek harus mengeluarkan biaya pelatihan dan waktu pelatihan yang lumayan lama. Perlu dipertimbankan kembali mengenai keharusan mengikuti pelatihan Midwifery Update (MU) untuk mendapatkan rekomendasi dari Organisasi Profesi (IBI).

b. Faktor Sarana dan Fasilitas Praktik Mandiri Bidan.

Dalam Peraturan Menteri Kesehatan Nomor 28 tahum 2017 pasal 34 disebutkan bidan persyaratan prasarana praktik mandiri termasuk peralatan praktik mandiri, obat-obatan dan bahan habis pakai ditambah dengan pengelolaan limbah medis. Pengelolaan lombah medis sendiri daapt dilakukan melalui kerjasasama dengan institusi yang menyediakan instalasi pengelolaan limbah Medis. dalam melakukan kerja sama ini tentunya Bidan Praktik mendiri harus mengeluarkan biaya yang tidak murah. Sementara itu pngelolaan peralatan yang perlu dikalibrasi, sehingga seorang bidan praktik mandiri juga harus bekerjasama dengan instansi yang memiliki sarana kalibrasi dan hal ini juga mengeluarkan biaya yang tidak sedikit.

c. Perkembangan Media Online

Era digital juga membawa dampak yang cukup besar dalam kehidupan masyarakat. Masyarakat seolah-olah dipaksa untuk bertansformasi dari cara lama yang manual ke media digital dalam menjalani kehidupan mereka, salah satunya adalah dalam sektor perizinan. Pengajuan perizinan baik dalam pengurusan STR dan Perizinan SIP dilaksanakan melalui online. Untuk sebagian orang yang paham Media online pastinya hal ini sangat memudahkan namun bagi yang memiliki keterbatasan dalam 
menggunakan media online tentunya hal ini sangat menyulitkan. Bidan Praktik mandiri mayoritas mengeluhkan susahnya mengakses media online ketika mengurus STR dan melakukan registrasi perizinan. Di Provinsi DKI Jakarta Sendiri proses pengajuan perizinan bisa diakses melalui platform Jak-evo. Platform ini pihak yang mengajukan dapat melakukan registrasi termasuk mengunduh semua berkas administrasi. Media ini yang dipakai oleh pihak PTSP apakah pihak pemohon sudah melengkapi semua ketentuan persyaratan perizinan sebelum dilakukan tinjauan lapangan.

d. Pembinaan dan Pengawasan

Dalam Peraturan Menteri Kesehatan Nomor 28 tahum 2017 Bab IV pasal 40 disebutkan bahwa Dinas Kesehatan kabupaten/kota harus melakukan penilaian terhadap pemenuhan persayaratan bidan praktik mandiri bidan. Implementasi pemberian izin di Provinsi DKI Jakarta melibatkan 2 institusi yaitu Dina Penanaman Modal dan Dinas Kesehatan Kabupaten/kota (Suku Dinas Kesehatan Kota Administrasi). Pada saat penilaian ke dua institusi ini bersama-sama turun ke sarana praktik dan melihat langsung pemenuhan persyaratan perizinanan. Suku Dinas kesehatan memberikan rekomendasi ke PTSP agar diterbitkan izin apabila semua persayaratan sudah dipenuhi oleh pihak pemohon. Pada Bab VI pasal 46 disebutkan bahwa Menteri, Kepala Dinas Kesehatan Provinsi dan/atau Kepala Dinas Kabupaten/Kota melakukan pembinaan dan pengawasan terhadap pelaksanaan praktik bidan sesuai dengan kewenangan masing-masing. Pada pelaksananya kegiatan evaluasi atau pengawasan terhadap Bidan Praktik Mandiri (BPM) di Dinas Kesehatan Provinsi DKI Jakarta dilaksanakan Oleh Suku Dinas Kesehatan. Pada pelaksanaannya masih ditemukan kendala karena terbatasnya tenaga yang tersedia di Suku Dinas Kesehatan sehingga Pelaksanaan pengawasan Bidan praktik mandiri tidak dapat dilaksanakan secara menyeluruh. Kekurangan tenaga dan tugas di seksi Sumber Daya Kesehatan Dasar (SDK) belum dapat melakukan semua pengawasan praktik mandiri.

e. Faktor Penegak Hukum Suku Dinas Kesehatan Kota Adminsitrasi

Pelaksanaan Pengawasan dan monitoring evaluasi belum dijalankan berjalan dengan baik terutama dalam hal penegakan hukum apabila ditemukan adanya Pranktik mandiri Bidan Mandiri yang tidak memiliki SIPB. Penegakkan Permenkes Nomor 28 tahum 2017 belum sepenuhnya dilaksanakan oelh Suku Dinas Kesehatan Kota Adminsitrasi sehingga membuat Bidan Praktik Mandiri (BPM) tidak merasa wajib untuk melengkapi segala fasilitas tempat, peralatan dan obat- obatan ketika melaksanakan Praktik Mandiri. Penegakan hukum ini termasuk pemberian Surat peringatan (SP), dan penutupan sementara praktik mandiri samapai izin praktik mandiri yang tebaru terbit. penegakan hukum ini dirasa berat karena proses ini harus mengikuti bebrapa prosesur termasuk koordinasi dengan beberapa phak termasuk Organisasi Profesi (IBI), PTSP, Satuan Pamong Praja dan Puskesmas Setempat. Perlu dikoordinasikan prosedur penutupan tempat praktik yang tidak memiliki izin dan aspek etis lainnya sehingga tidak ada pihak yang merasa dirugikan. 
f. Faktor Masyarakat dan Kebudayaan

Faktor ini berhubungan dengan tingkat kepatuhan serta kesadaran hukum masyarakat dalam memiliki izin dalam melakukan praktik Mandiri Bidan. Masyarakat yang dimaksud dalam hal ini sesuai dengan Permenkes Nomor 28 tahum 2017 adalah adalah tenaga Bidan yang menjalankan Praktik Mandiri, di Wilayah Provinsi DKI Jakarta. Bidan yang menjalankan dan yang akan mengurus Izin Praktik Mandiri belum memahami penuh isi dari dengan Permenkes Nomor 28 tahum 2017 dan kurangnya sosialisai yang dilakukan oleh institusi terkait. Hal ini memungkinkan Bidan praktik mandiri tidak mengetahui kekurangan yang mungkin terjadi. 


\section{BIBLIOGRAFI}

Annabel et.all. (2018). Midwives 'with woman' in the private obstetric model: Where divergent philosophies meet. Australia: Elsevier Ltd. Google Scholar

Dewi, Indah Kusuma. (2021). Sosialisasi Legalitas Usaha Kaopi Sebagai Solusi Peningkatan Usaha Mikro Pada UMKM Kaopi di Desa Kolowa Kecamatan Gu Kabupaten Buton Tengah. Jurnal Pengabdian Pada Masyarakat Membangun Negeri, 5(1), 276-287. Google Scholar

Et.all, Michelle. (2020). Potential impact of midwives in preventing and reducing maternal and neonatal mortality and stillbirths: a Lives Saved Tool modelling study. United ingdom: Thelanced.

Firmanto, Aditia Arief. (2019). Perlindungan Hukum Pasien Pada Bidan Praktik Mandiri Di Indonesia Pasca Dikeluarkannya Undang-Undang Nomor 4 Tahun 2019 Tentang Kebidanan. Pranata Hukum, 14(2), 140-156. Google Scholar

Hajriati, Isma, Arman, Arman, \& Muchlis, Nurmiati. (2021). Analisis Sistem Perencanaan Tenaga Kesehatan Di Wilayah Kerja Dinas Kesehatan Kabupaten Barru: Analysis of the Health Personnel Planning System in the Work Area of the Barru District Health Office. Journal of Muslim Community Health, 2(4), 103-116. Google Scholar

Jayanti, Ratna Dwi, Keb, S., Anis, Wahyul, \& Keb, S. (2021). Simulasi dalam Pendidikan Kebidanan. Airlangga University Press. Google Scholar

Lette, Arman Rifat Lette. (2020). Jumlah dan Kebutuhan Sumber Daya Manusia Kesehatan di Fasilitas Kesehatan Kota Kupang. Jurnal Publikasi Kesehatan Masyarakat Indonesia, 7(2). Google Scholar

Lutfiana, Indrie, \& Wulandari, Ni Ketut Ayu. (2020). Aspek Hukum Pelaksanaan Kewenangan Bidan Dalam Pelayanan Kebidanan. Midwinerslion: Jurnal Kesehatan STIKes Buleleng, 5(1), 211-218. Google Scholar

Nomor, Peraturan Pemerintah Republik Indonesia. (28AD). Tahun 2017 tentang Izin dan Penyelenggaraan Praktik Bidan.

Nursalam, D. M. (2013). Metodologi penelitian ilmu keperawatan. Jakara: Salemba Medika. Google Scholar

Nuryuniarti, Rissa, \& Nurmahmudah, Endah. (2019). Regulasi Hukum Bagi Bidan Dalam Melakukan Asuhan Kebidanan Pada Balita Di Bidan Praktik Mandiri Menurut Permenkes Nomor 28 Tahun 2017 Tentang Izin Dan Penyelenggaraan Praktik Bidan. Jurnal Ilmiah Galuh Justisi, 7(2), 1-24. Google Scholar

Telaumbanua, Dalinama. (2019). Undang-Undang Republik Indonesia Nomor 4 Tahun 2019 tentang Kebidanan. Google Scholar 


\section{Copyright holder:}

Edward Lumban Raja, Puput Oktamianti (2022)

First publication right:

Syntax Literate: Jurnal Ilmiah Indonesia

This article is licensed under:
(cc) (i) () 